\title{
POTENTIAL IMMUNE EFFECTS OF DIETARY PRO-BAC PROBIOTIC ON AFRICAN SHARPTOOTH CATFISH (CLARIAS GARIEPINUS)
}

\author{
HASSAN AHMED ${ }^{1}$; WALAA F.A. EMEISH ${ }^{2}$ and ZEINAB AL-AMGAD ${ }^{3}$ \\ ${ }^{1}$ Department of Physiology, Faculty of Veterinary Medicine, South Valley University, Qena 83523, Egypt. \\ ${ }^{2}$ Department of Fish Diseases, Faculty of Veterinary Medicine, South Valley University, Qena 83523, Egypt. \\ ${ }^{3}$ Veterinary National Service, PhD in Veterinary Pathology and Clinical Pathology, Faculty of \\ Veterinary Medicine, South Valley University, Qena, Egypt.
}

Received: 21 June 2018; Accepted: 29 July 2018

\begin{abstract}
The present study is designed to investigate the Pro-bac, a commercial probiotic as an immunostimulant, growth promoter and antibacterial, for African Sharptooth Catfish, Clarias gariepinus. The immuno-potentiation effects of Pro-bac probiotic were investigated after 30 successive days of dietary supplementation of catfish. Seventytwo apparently healthy catfish with average body weight of $50 \pm 5 \mathrm{~g}$ were used. Twenty-four fish were used to investigate some biochemical and immune parameters. In addition, forty-eight fish were used as challenge test with virulent Aeromonas hydrophila strain to evaluate the ability of fish received the feeding additives to resist diseases. Histopathological exam of liver, kidney and spleen were also investigated. Our results proved that, oral supplement of probiotic stimulate the non-specific immunity at cellular and humoral levels as indicated by the enhanced lymphocytes level, increased total proteins, albumins and globulins. Moreover, kidney functions were improved in the probiotic group, which measured by the significant decreased in urea level. The level of sodium, potassium and chloride were increased significantly in probiotic group than in control diet. Besides, weight gain of catfish was significantly increased in the probiotic group than in the basic diet group. The mortality percent of fish fed with probiotic ration and subjected to infection challenge with A. hydrophila were significantly lower than those that received the basic diet. Histopathological examination showed normal histological structure of liver, kidney and spleen. The present study clearly demonstrated that Pro-bac mixture of probiotics had significant stimulating effects on the immune system and disease resistance of $C$. gariepinus.
\end{abstract}

Key words: Catfish, probiotics, Immunostimulant effect, Electrolytes, Growth rate, Aeromonas hydrophila.

\section{INTRODUCTION}

In the field of aquaculture, now Egypt is considered as one of the most growing countries (FAO, 2005). Among cultured fish, African Sharptooth Catfish, C. gariepinus belongs to the family Claridae, is the most commonly fresh water fish species and is dominant in aquaculture practice in Egypt. They are easily cultured with large economic outcomes because they have a function of airbreathing, convenient reproduction, high feed conversion rate and great growth rate in a short time (Fagbenro, 1998). However, infectious diseases are the most notable etiologies that put the live of fishes at risk with subsequent adverse effect on growth and productivity (Diab et al., 2004; Eissa et al., 2009). A. hydrophila is the most pathogenic bacteria which has deleterious pathogenic effect on fish such as

Corresponding author: Dr. HASSAN AHMED

E-mail address: hassan-younes@vet.svu.edu.eg

Present address: Department of Physiology, Faculty of Veterinary

Medicine, South Valley University, Qena 83523, Egypt. hemorrhagic septicaemia, infectious dropsy, tropical ulcerative disease and fin rot that subsequently lead to drastic mortality in fish farms (Karunasagar et al., 1997). Although chemotherapy, antibiotics and chemical disinfectants were the traditional strategies for disease control, they give partial success (Stoskopf, 1993) and become no longer proposed practices due to the danger of bacterial resistance (Aoki et al., 1985), and yields fish residues and moreover, introducing high risks to the human health and environment. Therefore, the fish health care and improvement of their immunity are of primary concern.

Immunostimulants proved to give some success and environmentally friendly application, for disease control (Peddie et al., 2002; Yeh et al., 2008). Current evidence shows that, uses of probiotic bacteria in aquaculture has been suggested to become an alternative and a modest method for the management of various diseases (Direkbusarakom et al., 1998; Irianto and Austin, 2002) and are important for fish immune response. Probiotic administration 
potentiates the immunity by enhancing phagocytic process, ability of engulfing as well as lysis of invaded bacteria and production of immunoglobulins (Nikoselainen et al., 2003; Choudhury et al., 2005; Panigrahi et al., 2005; Song et al., 2006). The application of multi-species probiotics as feed complements is supposedly more influential than mono-species probiotics as a result of more diversity in antimicrobial compounds (Nayak, 2010). Pro-bac, a commercial probiotic used in the current study, is a multi-species probiotic, consisting mainly of a variety of lactic acid bacteria and enzymes and yeast specie, Saccharomyces cervisiae. Non-specific immune systems are very important in the defense mechanisms of fish against pathogens and microorganisms. Therefore, the aim of the present study was to examine some innate immune parameters and weight gain in African Sharptooth Catfish, Clarias gariepinus and its resistance against virulent strain of A. hydrophila following dietary administration of commercial compound probiotics (Pro-bac). In addition, the histological structure of kidney, liver and spleen were also examined.

\section{MATERIALS AND METHODS}

\section{Fish specimens}

Two hundred apparently healthy African Sharptooth Catfish, C. gariepinus, with average body weight $50 \pm$ $5 \mathrm{~g}$ were obtained from private fish farm in ElDakahlea Governorate. The fish were transported to the aquatic research laboratory at Faculty of Veterinary Medicine, South Valley University, Qena. Fish were kept under laboratory conditions in plastic aquaria filled with dechlorinated tap water for adaptation 3 weeks before starting the experiments and fed on basic diet without probiotics twice daily with feeding rate of $3 \%$ of their body weight. Moreover, a $12 \mathrm{~h}$ dark: $12 \mathrm{~h}$ light photoperiod was provided. The water temperature was maintained at $25 \pm 2{ }^{\circ} \mathrm{C}$ throughout the experiment. Water was changed day after day throughout the experimental period and the fecal matters were siphoned out daily.

\section{Experimental diets}

The basic diet was consisted of grounded yellow corn $34.9 \%$, vegetable bean meal $28.6 \%$, fish meal $17.0 \%$, wheat bran $9.3 \%$, mineral mixture $1.7 \%$ and vitamin mixture $1.0 \%$, the basal diet was used as the control diet. Experimental diets containing a commercial probiotics product (Pro-bac, a commercial probiotic) were added to basic diet to reach final concentration of $5 \mathrm{gm} / \mathrm{kg}$ diet, (Produced by Vigora, Reg.No.: M.O.A.:8151) and contains: LAB culture $2.0 \times 10^{7}$ CFU/gm total bacteria (Lactobacillus acidophilus, $L$. Planterum, L. Bervis and Bifidobacteria), Enzymes blend concentrate, Amylase 3.45 units/gm, Betaglucanase, Hemicellulase, and S. cervisiae 100 $\mathrm{mg} / \mathrm{gm}$. The dietary ingredients were thoroughly mixed and prepared using a hand palletizer, then stored at $-5{ }^{\circ} \mathrm{C}$ until used and the required amount of the diet was prepared every week.

\section{Experimental design}

Seventy-two acclimatized catfish were used in this experiment which was separated into two major experiments:

1. Experiment 1 for evaluation of immune and biochemical parameters; it includes two groups:

- Group I (control group) was fed on basic diet $(n=12)$.

- Group II (probiotic group) was fed on basic diet containing probiotic at concentration of 5 $\mathrm{gm} / \mathrm{kg}$ diet $(\mathrm{n}=12)$.

2. Experiment 2 for challenge test; it includes:

- Group III (control group): was fed on basic diet and injected with bacteria.

- Group IV: was fed on basic diet containing probiotic at concentration of $5 \mathrm{gm} / \mathrm{kg}$ diet and injected with bacteria.

- Group V (+ve control): was fed on basic diet and injected with saline.

- Group VI (-ve control): was fed on basic diet and remained without injection.

Fish were fed twice daily for 30 successive days and body weight was recorded at the start and the end of the experiments. Note that all the experiments were done in 3 replicates.

\section{Fish sampling}

At the end of the experiment, blood samples were collected from group I and II immediately. For this purpose, fish were quickly anesthetized using tricaine methanesulfonate (MS-222, Argent Chemical Labs, Redmond, Washington, USA). Then blood was drawn from caudal vein and was collected in Eppendorf tubes.

Blood smears were made immediately for differential leukocytic count. Then the collected blood was allowed to clot for 2 hours at $4^{\circ} \mathrm{C}$ then centrifuged at $3000 \mathrm{rpm}$ for $15 \mathrm{~min}$. Sera were collected and kept at $-20^{\circ} \mathrm{C}$ until being used for immune and other biochemical assays. Blood smears were stained by Giemsa stain then examined under light microscope and the cells were identified according to the morphological features, differential leukocyte counts (DLC) (neutrophil, lymphocyte, monocyte, basophils and eosinophils) were determined according to Stoskopf (1993) by counting of 100 cells and percent of each type was calculated. 


\section{Biochemical analysis}

All biochemical parameters were monitored spectrophotometrically according to standard methods using commercial laboratory kits. Total serum proteins $(\mathrm{g} / \mathrm{dl})$ analyzed according to Kaplan and Szabo (1983) and albumin (g/dl) according to Doumas et al. (1971). Total proteins and albumin kits (Spectrum, Egyptian Company for Biotechnology, Obour City, Cairo, Egypt) were used. Globulin level $(\mathrm{g} / \mathrm{dl})$ was calculated mathematically by subtracting albumin value from total protein value (Busher, 1990). In addition, urea assessed according to young et al. (1975) (Egy-chem, Badr city, Egypt), creatinine according to Tietz (1986), Sodium according to Henry et al. (1974), potassium according to Hilman et al. (1967) and chloride according to Bablok et al. (1988) (Spectrum, Egyptian Company for Biotechnology, Obour City, Cairo, Egypt).

\section{Experimental challenge test Bacterial strain}

An Aeromonas hydrophila virulent strain which was positive for cytotoxic enterotoxin (act) and aerolysin (aerA) virulence genes and was isolated from clinical cases of infected fish showing signs of septicemia was used in the experimental infection (article in press). The strain was identified by Gram stain, motility test, and various biochemical characters according to Austin and Austin (2016), confirmed at genus level by using GyrB gene (Yanez et al., 2003), defined at species level by restriction fragment length polymorphism (RFLP) analysis of 16S rDNA (Ghatak et al., 2007) and preserved in glycerol at $80^{\circ} \mathrm{C}$. To resume its pathogenicity, A. hydrophila strain was passed three times in healthy catfish through intra-peritoneal injection before using for experimental challenge.

\section{Bacterial challenge suspension and counts}

Colony forming units (cfu) counts in bacterial suspensions were determined spectrophotometrically through optical density values at wavelength of 600 $\mathrm{nm}$ and standard-plate-count method with ten-fold serial dilution (Elkamel and Thune, 2003).

\section{Experimental infection}

At the end of the experiment, 12 fish from each treated group (group III and IV) of challenge test were injected with $0.5 \mathrm{ml}$ through intra-peritoneal injection in $6 \times 10^{6} \mathrm{cfu} / \mathrm{ml}$ of $a c t^{+} a e r A^{+}$A. hydrophila, a control group (group $\mathrm{V}, \mathrm{n}=12$ ) were I.P. injected with sterile saline and another control group (group VI, $n=12$ ) was remained un-injected. The challenge trial lasted for 15 days. Mortality rate was recorded; dead fish were removed daily and subjected to bacterial re-isolation.

\section{Histopathological examination}

After blood collection, liver, kidney and spleen of the sacrificed catfish were immediately examined for any gross lesions, then dissected out and fixed in $10 \%$ neutral buffered formalin. Paraffin sections of 4-5 $\mu \mathrm{m}$ thick were prepared and stained with Harris hematoxylin and eosin for the routine histopathological examination as described by Bancroft and Gamble (2008).

\section{Statistical analysis}

Results were analyzed statistically by using the Graph-Pad Prism (GraphPad Software, San Diego, CA, USA). Values were expressed as mean \pm standard error of mean (SEM) and differences between groups were analyzed by using Student's $t$ test, results were considered significant at the $\mathrm{P}<0.05$ level.

\section{RESULTS}

During the experimental period, there was no noticeable mortality or abnormal fish behavior in all treatments during the feeding trial.

Results of the current study showed in fig. (1) revealed that the lymphocytes (\%) of catfish fed on the probiotic diet (group II) were significantly higher $(\mathrm{P}<001)$ than those of fish fed on basic diet $(89.33 \pm 1.39$ and $59.58 \pm 1.68 \%$, respectively); while neutrophils and monocytes $(\%)$ were significantly $(\mathrm{P}<0.001)$ decreased $(9.58 \pm 1.23$ and $0.50 \pm 0.23 \%$, respectively) compared with basic diet-treated group (group I) $(30.58 \pm 1.76$ and $6.58 \pm 0.63 \%$, respectively). Moreover, probiotic decreased the percent of basophils significantly $(\mathrm{P}<0.001) \quad(0.25 \pm 0.18 \%)$ incomparable to group received probiotic free diet $(1.83 \pm 0.37 \%)$. In addition, there was non-significant reduction in eosinophils percent with $(0.33 \pm 0.22 \%)$ and without $(1.42 \pm 0.51 \%)$ probiotic administration. 


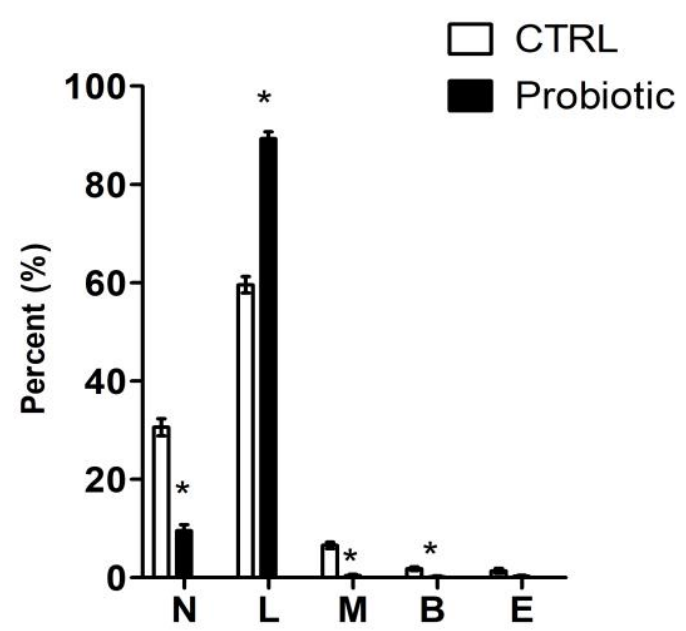

Fig. 1: Effect of two diets, basic (no additives), and a Pro-bac diet (basic diet with $5 \mathrm{gm} / \mathrm{kg}$ diet) used to feed catfish, on the differential leukocytic counts. ( $\mathrm{L}=$ Lymphocytes, $\mathrm{N}=$ Neutrophils, $\mathrm{M}=$ Monocytes, B- Basophils, $\mathrm{E}=$ Esinophils). Asterisks on the bars denote significant difference from the Pro-bac diet-treated values $(\mathrm{P}<0.05)$. Data represent the average of 3 experiments.

Catfish received probiotic in diet (group II) exhibited variable changes in biochemical parameters compared with control (group I). Fig. 2A showed body proteins markedly elevated after probiotic administration; serum level of total protein significantly increased $(\mathrm{P}<0.01)(7.64 \pm 0.24 \mathrm{~g} / \mathrm{dl})$, serum level of albumin significantly raised $(\mathrm{P}<0.001)(2.15 \pm 0.05 \mathrm{~g} / \mathrm{dl})$, serum level of globulins significantly elevated $(\mathrm{P}<0.01)$ $(5.49 \pm 0.23 \mathrm{~g} / \mathrm{dl})$ compared with their corresponding control $(6.27 \pm 0.27,1.81 \pm 0.06$ and $4.46 \pm 0.25 \mathrm{~g} / \mathrm{dl}$ respectively). Howevere, $\mathrm{A} / \mathrm{G}$ ratio slightly reduced non-significantly after probiotic administration $(0.40 \pm 0.02 \%)$ compared with that after basic diet administration $(0.42 \pm 0.03 \%)$. Interestingly, Catfish showed improvement of kidney function (Fig. 2B) represented by significant decrease serum urea level $(\mathrm{P}<0.001)(8.44 \pm 0.23 \mathrm{mg} / \mathrm{dl})$ compared with control fed on basic diet $(8.68 \pm 0.23 \mathrm{mg} / \mathrm{dl})$ while, there is slightly increase in serum creatinine level $(0.39 \pm 0.02$ $\mathrm{mg} / \mathrm{dl})$ compared with control $(0.35 \pm 0.02 \mathrm{mg} / \mathrm{dl})$.
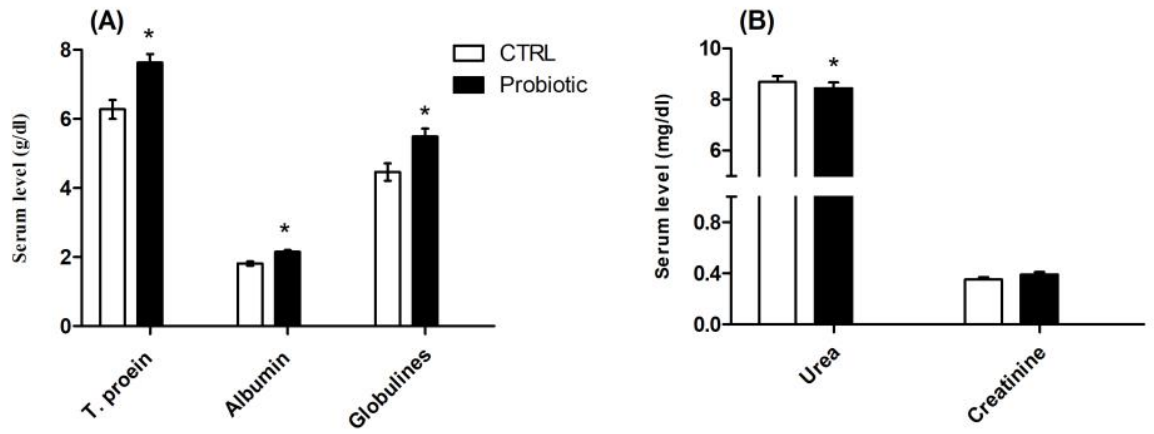

Fig. 2: Effect of two diets, basic and a Pro-bac diet (basic diet with $5 \mathrm{gm} / \mathrm{kg}$ diet) used to feed catfish, on the different serum biochemical parameters. (A) Total proteins, albumin and globulins significantly increase in fish received pro-bac diet compared with corresponding control. (B) Serum level of urea significantly decrease in fish received pro-bac diet compared with control while, creatinine showed slight elevation. Asterisks on the bars denote significant difference from the Pro-bac diet-treated values $(\mathrm{P}<0.05)$. Data represent the average of 3 experiments.

Surprisingly, serum level of electrolytes represented in $\mathrm{Na}^{+}, \mathrm{Cl}^{-}$and $\mathrm{K}^{+}$exhibited variant increase in probac-treated group (Fig. 3). Serum level of $\mathrm{Na}^{+}$ significantly increased $\quad(\mathrm{P}<0.01) \quad(157.33 \pm 3.38$ $\mathrm{mEq} / \mathrm{L})$ compared with corresponding control $(138.10 \pm 3.85 \mathrm{mEq} / \mathrm{L})$, in the same manner, serum level of $\mathrm{Cl}^{-}$increased significantly $(\mathrm{P}<0.05)$ $(115.68 \pm 3.75 \mathrm{mmol} / \mathrm{L})$ compared with control group $(102.93 \pm 3.60 \mathrm{mmol} / \mathrm{L})$. Moreover, serum $\mathrm{K}^{+}$level also, highly significantly increased $(\mathrm{P}<0.001)$ $(6.34 \pm 0.39 \mathrm{mmol} / \mathrm{L})$ compared with control $(3.83 \pm 0.25 \mathrm{mmol} / \mathrm{L})$. 


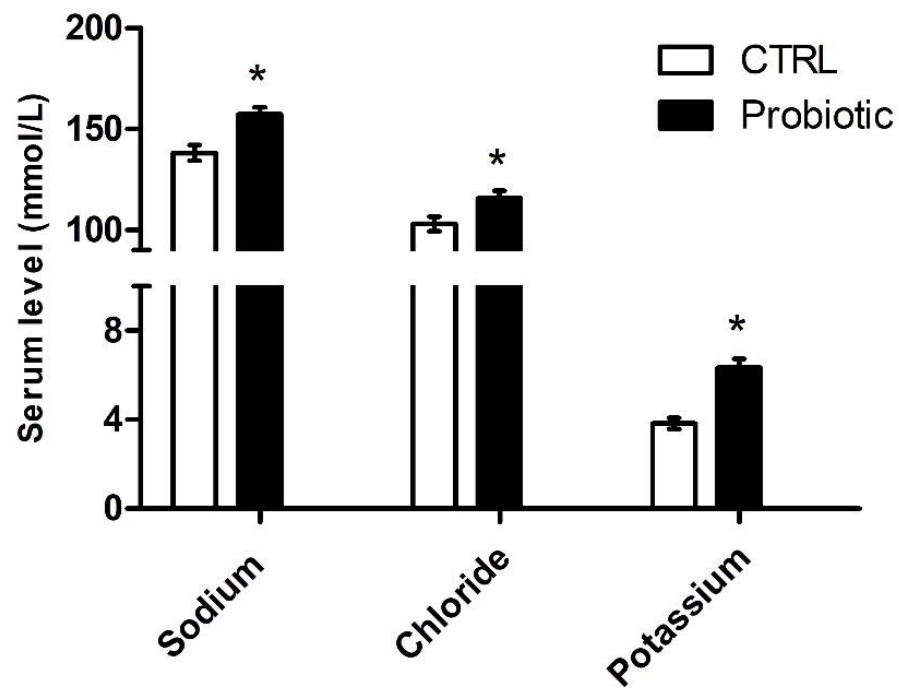

Fig. 3: Effect of two diets, basic and a Pro-bac diet (basic diet with $5 \mathrm{gm} / \mathrm{kg}$ diet) used to feed catfish, on the serum electrolytes level. Asterisks on the bars denote significant difference from the Pro-bac diet-treated values $(\mathrm{P}<0.05)$. Data represent the average of 3 experiments.

Expectedly, after the end of the experiment, body weight gain was increase significantly $(\mathrm{p}<0.001)$ $(49.67 \pm 2.71 \mathrm{~g})$ after probiotic supplement compared with fish fed on basic diet $(36.25 \pm 2.76 \mathrm{~g})$ (Fig 4A). Regarding to challenge test to investigate the fish resistance to virulent $A$. hydrophila strain, Catfish in group IV (fed on probiotic and injected with bacteria) showed improvement in resistance as the cumulative mortalities were significantly reduced almost around to the half $(36.71 \%)$ than that fed on basic diet (group III) (66.70\%) (Fig. 4B). In addition, there were no mortalities, or any noticeable clinical signs recorded in the control +ve or -ve control groups.
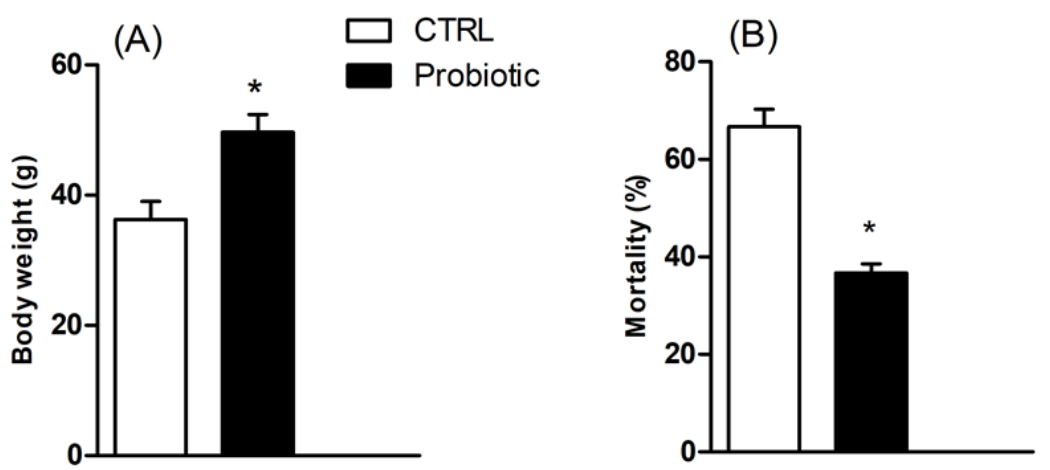

Fig. 4: Effect of two diets, basic and a Pro-bac diet (basic diet with $5 \mathrm{gm} / \mathrm{kg}$ diet) used to feed catfish, on the weight gain (A) and cumulative mortality percent of fish challenged with Aeromonas hydrophila. Asterisks on the bars denote significant difference from the Pro-bac diet-treated values $(\mathrm{P}<0.05)$. Data represent the average of 3 experiments.

Grossly, the control group demonstrated apparently intact internal organs of normal coloration, shapes and consistency. Few sacrificed catfish of this group displayed friable liver in addition to darkish discoloration of spleen reflected mild degree of congestion. The probiotic group showed normal anatomical gross appearance of the parenchymatous organs. Since, liver appeared brown in color with brightness appearance. Kidney and spleen showed darkish red coloration with intact consistency.

Microscopically, Liver of the control catfish displayed normal histological structure of hepatocytes arranged in hepatic cords with polygonal shaped cells; in addition, few hepatocytes were suffered from mild degree of cytoplasmic vacuolation. Liver showing slight portal and periportal inflammation with few number of mononuclear cells infiltration mainly lymphocytes (Fig. 5a \& b). Probiotic group improved and corrected the hepatocellular structure since the liver exhibited normal hepatocytes architecture (Fig. 5c), besides hyperactivation and proliferation of the Kupffer cells and melanomacroghages centers (Fig. 5d). 

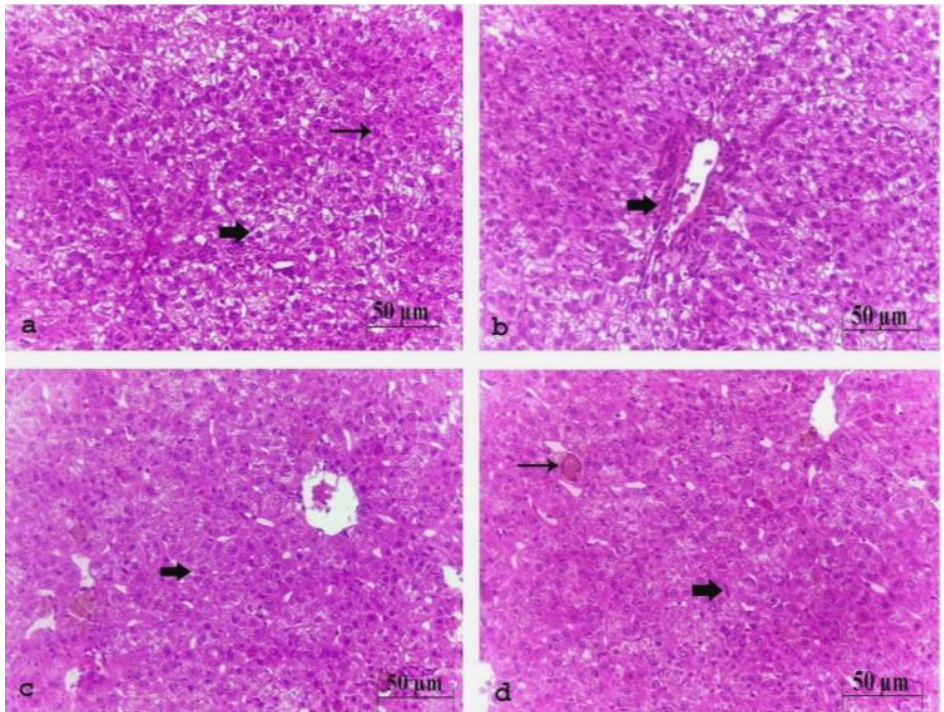

Fig. 5: Photomicrograph of liver of the control catfish showing normal histological structure of hepatocytes in cords with polygonal shapes (thin arrow), besides mild hepatic vacuolation (thick arrow) (a). Liver showing normal architecture of the hepatic tissues, in addition to slight portal inflammation (b). Photomicrograph of the liver of the probiotic-treated catfish showing normal arranged hepatocytes (c). Liver showing hyperactivation and proliferation of the Kupffer cells (thick arrow) and melanomacroghages (thin arrow) $(\mathbf{d}) . \quad(\mathbf{H \& E}, \mathbf{b a r}=\mathbf{5 0} \boldsymbol{\mu m})$

The posterior kidney of the control group demonstrated normal histological structure of the nephrons comprising intact glomeruli with mild vacuolar degeneration of the renal tubules (Fig. 6a \& b). The posterior kidney of the probiotic-treated group showed normal appearance of glomeruli and restored the histological appearance of the convoluted tubules and collecting ducts (Fig. 6c), in addition there was normal areas of the haemopoietic tissues comprising lymphocytes and macrophage cells infiltration (Fig. 6d).
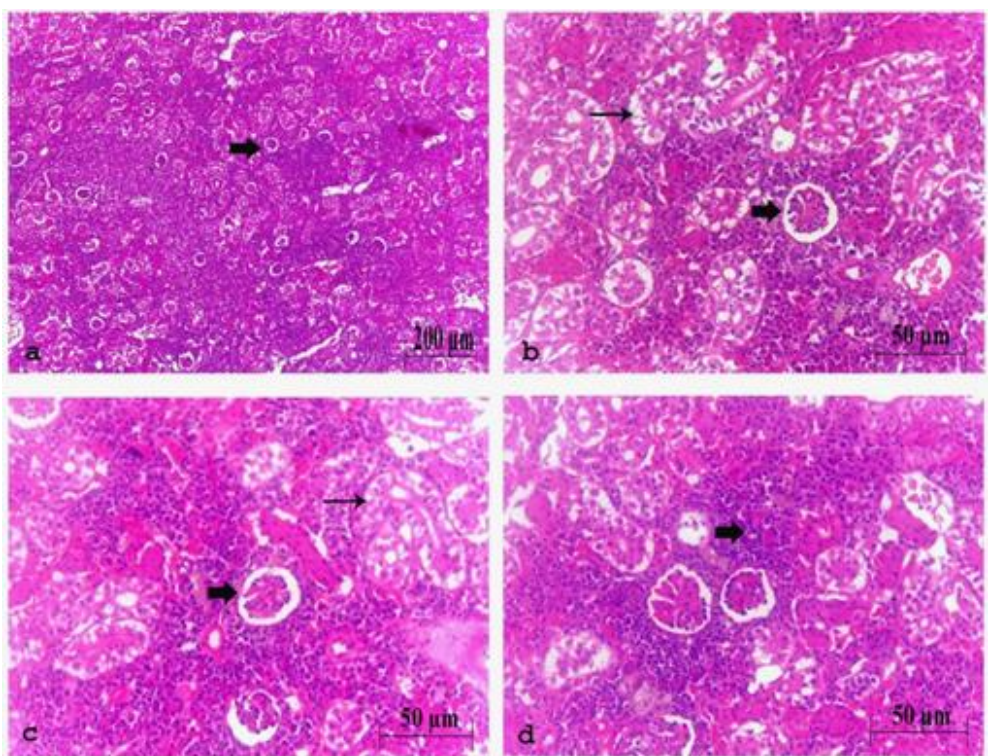

Fig. 6: Photomicrograph of the posterior kidney of the control catfish showing normal histological structure of the nephrons comprising intact glomeruli with mild vacuolation of the renal tubules (a), high power of (a) to show normal histological structure of the glomeruli (thick arrow), besides mild vacuolar degeneration of the renal tubules (thin arrow) (b). Photomicrograph of the posterior kidney of the probiotic-treated catfish showing normal glomeruli (thick arrow) and convoluted tubules (thin arrow) (c), in addition to normal areas of the haemopoietic tissues with lymphocytes and macrophage cells infiltration (thick arrow) $(\mathbf{d})$. (H\&E, bar= $\mathbf{5 0} \boldsymbol{\mu m})$.

The anterior kidney of control catfish showed intact haemopoietic tissues; since it eventually infiltrated with lymphocytes and macrophage cells (Figs. 7a \& b). On the contrary, the probiotic group recorded histological criteria of the haemopoietic tissues (Fig. $7 \mathrm{c}$ ), besides there was intense lymphocytes and macrophage cells infiltration (Fig. 7d). 

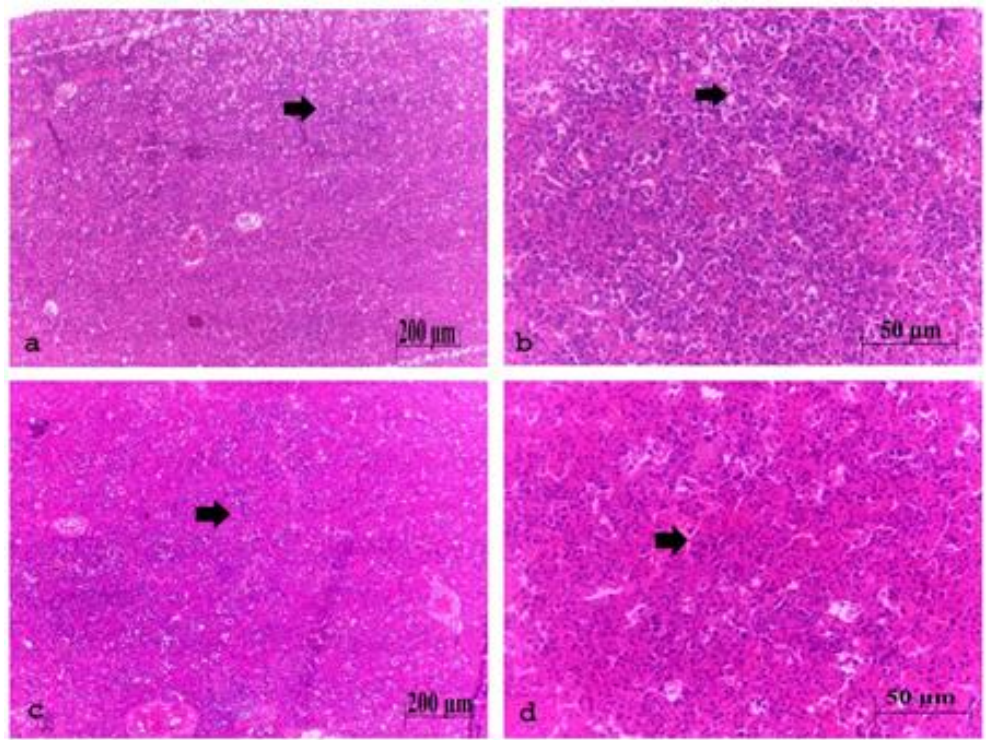

Fig. 7: Photomicrograph of the anterior kidney of the control catfish showing haemopoietic tissues normally infiltrated with lymphocytes and macrophage cells (a), high power of (a) to show normal arranged haemopoietic tissues with lymphocytes and macrophage cells (b). Photomicrograph of the anterior kidney of the probiotic treated catfish showing normal histological criteria of the haemopoietic tissues (c), besides lymphocytes and macrophage cells infiltration (d). (H\&E, bar= $50 \& 200 \mu \mathrm{m})$.

The splenic tissues of control group displayed normally arranged white and red pulp surrounded and protected with intact splenic capsule (Fig. 8a). There was slight degree of the lymphoid depletion of the white pulp was detected among few catfish (Fig. 8b). The probiotic-treated group showed alleviated mild changes of the lymphoid depletion which recorded in the control group, where it restored normal population of the splenic follicles with lymphocytes (Fig. 8c \& d). Additionally, there was pronounced infiltration of melanomacrophages cells adjacent to blood vessels and parenchyma (Figs. 8e \& f).
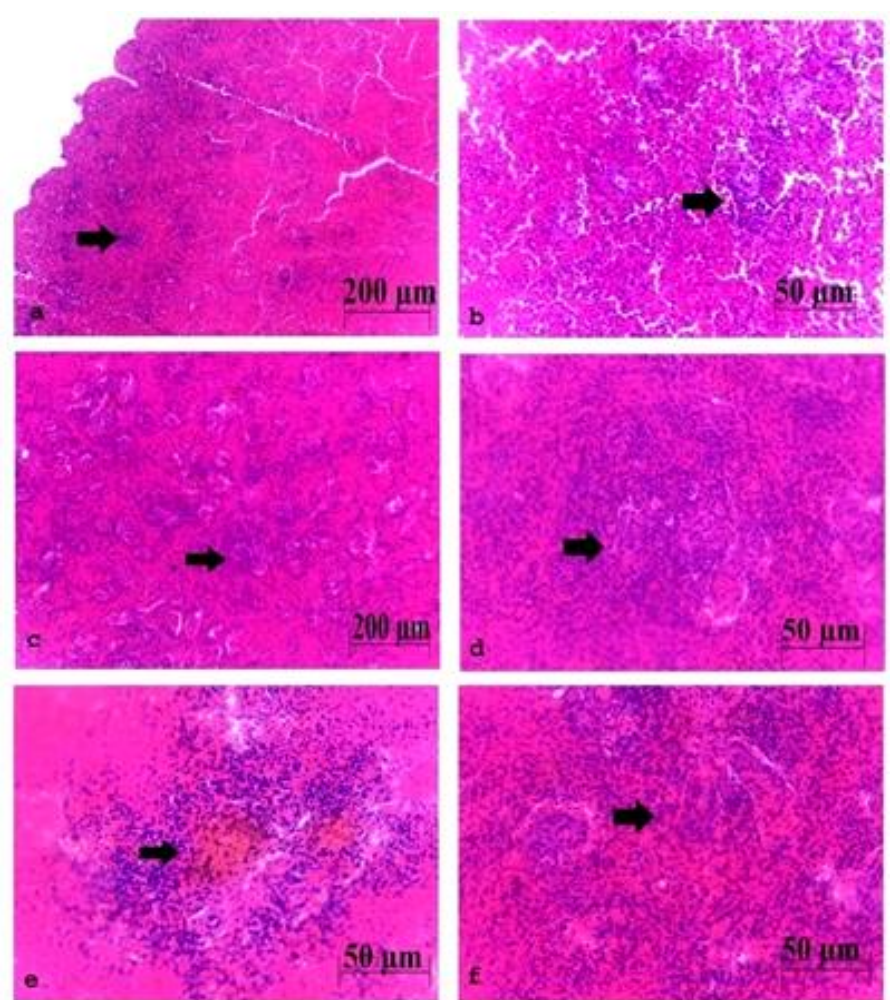

Fig. 8: Photomicrograph of the spleen of the control catfish showing normally arranged white and red pulp (a), high power of (a) to show slight degree of the lymphoid depletion (b). Photomicrograph of the spleen of the probiotic-treated catfish showing normal lymphoid population (c), high power of (c) to show normal lymphoid population (d), in addition to lymphocytes and macrophage cells infiltration (e \& f). (H\&E., bar= $50 \& 200 \mu \mathrm{m})$. 


\section{DISCUSSION}

Considerable studies have proved that immunostimulants can keep fish against bacterial pathogens, and a massive range of immunostimulants has been applied in aquaculture to stimulate growth and resistance against infections at stressful conditions. Immunostimulants can boost the immune system; its effect was strongly on innate defense mechanisms, (Kunttu et al., 2009) which considered more important for fish as it was the first line of defense against varying pathogens (Saurabh and Sahoo, 2008). Among immunostimulants, probiotics are live microbial or cultured product feed supplements, which proved to be good alternative husbandry methods to overcome the drawbacks of using antibiotics and beneficially affect the host by producing suppressing materials, competitive for activity sites, enhancing immune activity, and enhance the microbial balance (Fuller, 1989; Verschuere et al., 2000).

Therefore, we conducted this experiment to explore the effectiveness of commercial compound probiotics as a means to increase innate resistance of African Sharptooth Catfish, $C$. gariepinus against $A$. hydrophila under laboratory circumstances. Innate immune function in treated fish was assessed, using several functional immune parameters, to verify the changes due to treatments with the stimulator. After this the fish were intraperitoneally challenged with $A$. hydrophila bacteria to test host resistance against the pathogen.

Throughout the experiment, the immune system of catfish responded to probiotic which were investigated after 30 days of successive dietary supplementation, resulting in enhanced immune function as demonstrated by weight gain, increased values of immune parameters relevant to innate resistance against bacterial challenges.

Different types of fish leukocytes play a key role in the cellular immunity and resistance to infectious pathogens. Lymphocytes is involved in acquired immunity especially antibody production and phagocytic efficiency (Roberts, 2001). The significant increases in lymphocytes counts in fish fed with the probiotic diets may be may be caused by the activation of the hemopoietic tissues. In addition, recent studies indicated that probiotics can stimulate the piscine gut associated lymphoid tissue provoking an immune response (Nayak, 2010). All leucocytes were counted as a percentage of the whole leukocytic count which constitutes $100 \%$, so either increase or decrease in different leucocytes was pronounced in fish. The decrease of the percentage of neutrophils and monocytes in fish group fed on Pro-bac diet may be attributed to the significant increase of other leukocytic cells especially lymphocytes.
Body proteins represented in total protein and globulins contribute in monitoring immune system efficiency (Siwicki et al., 1994). In the current study, oral supplement of probiotic stimulates the nonspecific immunity at humoral level as measured through significant increase of total protein, albumin and globulins and reduced $\mathrm{A} / \mathrm{G}$ ratio. The previous studies proved that immune-potential effect of the probiotic on hepatic cells was mediated by enhancing anabolic activity to produce blood proteins (Marzouk et al., 2008), particularly globulins indicating a normal, positive and valuable effect of the experimentally used compound probiotic on the maintenance of the integrity of hepatocytes and their roles in improvement of liver histology (Kamgar et al., 2013), which proved in the histological findings of the current study. In addition, as it was the possible role of probiotic used in this experiment as an immunostimulant which composed of many ingredients such as Baker's Yeast (S. cerevisiae), which enhanced globulins level as observed in the present experiment. Previous researches proved that probiotic bacteria could increase the immunoglobulins production in fish (Nayak et al., 2007). Serum IgM levels has been elevated in fish after 30 days of administration of diet containing Baciilus pumilus or Bacillus clausii probiotics (Sun et al., 2010). The significant elevation in the total protein gives indication about the increase of the nutritional value of the diet. Decrease of $\mathrm{A} / \mathrm{G}$ ratio might be due to the high level of total globulin level (Sahoo and Mukherjee, 2001). This increase in serum immunoglobulin provides immediate and broad barrier against bacterial and viral agents (Whyte, 2007).

The results of urea showed a significant decrease in the probiotic group in compared with the basic diet one. Urea in fish is produced by liver and excreted by kidney (Stoskopf, 1993). The increase of urea in the basic diet group might be give indication about kidney dysfunction. In the same aspect, (Kamgar et al., 2013) reported increase of urea in control group than fish treated with probiotic. However, the used probiotic in this experiment didn't affect the creatinine level. Probiotics play a vital role in improvement of kidney function; for example, it decreases blood urea and creatinine levels in human suffering from chronic kidney disease (Miranda et al., 2014), rats (Bouhafs et al., 2015) and chicken (Iqramul Haque et al., 2017). However, the current study demonstrated decrease of uric acid but no significance changes in serum creatinine which is running parallel with previous findings in chicken (Hatab et al., 2016). In addition, decrease urea serum level after probiotic supplement indicting the ability of probiotic microorganisms in beneficial conversion of urea, uric acid and other toxic materials into nutrients which is utilized in the growth and body weight gain (Salim et al., 2011). 
Electrolytes are water-soluble charged ions in which needed for the body in specific concentrations to perform vital chemical reactions. They include potassium, sodium, calcium and magnesium. In our study, we determined electrolyte content $\left(\mathrm{Na}^{+}, \mathrm{Cl}^{-}\right.$, $\mathrm{K}^{+}$) in fish serum and they revealed significant differences. Sodium is the most considerable electrolyte in the body fluids intra and extracellular fluid; it controls water transport in the body's various fluid compartments, as well as the intra and extracellular water exchange (Ates et al., 2008). Chloride negative charged electrolyte found mainly extracellularly to balance sodium cations. Like sodium, it plays an essential role in water exchange and distribution inside and outside the cells. (Ates et al., 2008). Potassium contrasted with sodium, which is the major electrolyte outside the cell. Potassium plays a crucial role in muscle contraction, respiration and heart function (Bansal et al., 1979). The probiotic was successful in modulating catfish serum electrolytes in this study. The elevation in serum electrolytes may be caused by the process of ions uptake is stimulated by the chloride cells of the gills and decreased passive efflux of ions across the gill leading to haemo-concentration by decreased osmotic uptake of water across the gills. Besides, probiotics fortify gastrointestinal motility, enzyme activity and membrane transportation subsequently, augments nutrients absorption including electrolytes (Alkhalf $e t$ al., 2010). Increase electrolytes in blood after probiotics administration may be related to kidney function efficiency which improved by probiotics. In addition, adrenal gland which is the source of mineralocorticoids, may be activated by probiotics in relation to renal function improvement. The main function of mineralocorticoids is stimulation of $\mathrm{Na}^{+}$ and $\mathrm{Cl}^{-}$reabsorption from renal tubules and inhibits their excretion.

Results of the present study proved significant increase in body weight gain in probiotic group than the control. Similar results recorded by Ayoola et al. (2013) who proposed that the supplementation of probiotic (Lactobacillus and Bifidobacterium) improve the growth and rate of feed utilization of catfish. Also, Mohamed et al. (2007) reported that the Nile tilapia ( $O$. niloticus) fingerlings showed enhancing in growth rate after feeding with diet containing probiotic. Not only in fish, probiotic supplement augments the growth rate and feed conversion rate in chicken by decreasing gut $\mathrm{pH}$ through lactic acid production which in role stimulates enzymes activity like amylase, proteases and lipase. Moreover, probiotics is essential for metabolism of minerals, electrolytes and vitamins (Vit B1, B2, B12, Biotin and K) subsequently, proper growth and greater body weight gain (Dhama and Singh, 2010).
Results of the challenge experiment showed that, using pro-bac probiotic stimulate the immune system of catfish that positively impacted on the protection of fish to A. hydrophila infection. As the mortalities in bacterial challenge of fish having received probiotic was lower than that of untreated controls. Similar study has been reported to induce resistance in carp (Cyprinus carpio) against Edwardseilla tarda (Yano et al., 1989) and in Nile tilapia against $A$. hydrophila (Ali et al., 2010). The explanation for the decreased mortality of fish treated with probiotic was due to using probiotic could stimulating non-specific components of fish immune system that provide barrier against infectious bacterial agents and this could be proved in the selected measured innate immune parameters in this study. This immunostimulant effect as it results of increase lymphocytes which are producer of natural antibodies as well as globulins which are the main source of immunoglobulins.

In this study, probiotic diet could ameliorate the pathological changes and restored the normal histological criteria of some parenchymatous organs such as liver, kidney and spleen. Moreover, it showed high activation of Kupffer cells and melenomacrophage centers in liver and spleen (Marzouk et al., 2008). It could enhance both cellular and humeral immune response of the experimental fish. Such probiotics promoted resistance against the diseases (Huang et al., 2008), consequently alleviated pathological alterations. Probiotics have role on the maintenance and improvement of the integrity of hepatocytes and tissues (Safinaz, 2006). It has ability for the target renewal of the damaged and dead tissues. It also could suppress the oxidative damage induced in tissues (Abd El-Gawad et al., 2015), Moreover, it be considered as more protective agent for cells from damage or destruction caused by any foreign body through increasing oxygen and nitric oxide which produced by activated macrophages (Sharp and Secombes, 1993).

\section{CONCLUSIONS}

Results of the current study proved the efficient use of commercial compound probiotics as feed additives in African Sharptooth Catfish, C. gariepinus, as it enhanced the overall immune response as was indicated by the significant increase of the lymphocytes count, serum globulins and other selected biochemical parameters. Moreover, it has tremendous beneficial effect on the weight gain and improvement of kidney function by decreasing serum urea level. This modulation of the fish immunity has greatly stimulated the resistance of fish to $A$. hydrophila as was indicated by the significant decrease in mortalities in fish received the probiotics diet. 


\section{REFERENCES}

Abd El-Gawad, E.A.; Abd El-latif, A.M.; Amin, A.A. and Abd-El-Azem, M.A. (2015): Effect of Dietary Fructo-oligosaccharide on Bacterial Infection, Oxidative Stress and Histopathological Alterations in Nile Tilapia (Oreochromis niloticus). Global Veterinaria, 15 (4): 339-350.

Ali, H.M.; Ghazalah, A.A.; Gehad, E.A.; Hammouda, Y.A. and Abo-State1, H.A. (2010): Practical Aspects and Immune response of Probiotics Preparations Supplemented to Nile Tilapia (Oreochromis Niloticus) Diets. Nature and Science, 8: 39-45.

Alkhalf, A.; Alhaj, M. and Al-Homidan, I. (2010): Influence ofprobiotic supplementation on immune response of broiler chicks. Egyptian Poultry Science, 30: 271e280.

Aoki, T.; Knazawa, T. and Kitao, T. (1985): Epidemiological surveillance of drug resistant Vibrio anguillarum strains. Fish Patho., 20: 199-208.

Ates, B.; Orun, I.; Talas, Z.S.; Durmaz G. and Yilmaz, I. (2008): Effects of sodium selenite on some biochemical and hematological parameters of rainbow trout (Oncorhynchus mykiss albaum, 1792) exposed to $\mathrm{Pb} 2+$ and Cu2+. Fish Physiol Biochem, 34: 53-59.

Austin, B. and Austin, D.A. (2016): Bacterial fish pathogens.: Disease of farmed and wild fish, $6^{\text {th }}$ edition: $161-214$.

Ayoola, S.O.; Ajani, E.K. and Fashae, O.F. (2013): Effect of Probiotics (Lactobacillus and Bifidobacterium) on Growth Performance and Hematological Profile of Clarias gariepinus Juveniles. World Journal of Fish and Marine Sciences, 5(1): 01-08.

Bablok, W.; Passing, H.; Bender, R. and Schneider, B. (1988): A general regression procedure for method transformation. Application of linear regression procedures for method comparison studies in clinical chemistry, Part III. J Clin Chem Clin Biochem, 26(11): 783-790.

Bancroft, J.D. and Gamble, M. (2008): Theory and practice of histological techniques, Elsevier Health Sciences.

Bansal, S.K.; Verma, S.R.; Gupta, A.K. and Dalela, R.C. (1979): Physiological dysfunction of the haemopoietic system in a freshwater teleost Labeo rohita following chronic chlordane exposure. I. Alteration in certain hematological parameters. Bull Environ Contam Toxicol, 22: 666-673.

Bouhafs, L.; Moudilou, E.N.; Exbrayat, J.M.; Lahouel, M. and Idoui, T. (2015): Protective effects of probiotic Lactobacillus plantarum BJ0021 on liver and kidney oxidative stress and apoptosis induced by endosulfan in pregnant rats. Ren Fail.; 37(8): 1370-1378.
Busher, J. (1990): Serum albumin and globulin. In: Walker HK, Hall WD, Hurst JW, editors. Clinical Methods: The History, Physical, and Laboratory Examinations. 3rd edition. Boston: Butterworths. Chapter 101. Available from: http://www.ncbi.nlm.nih.gov/books/NBK204/.

Choudhury, D.; Pal, A.K.; Sahu, N.P.; Kumar, S.; Das, S.S. and Mukherjee, S.C. (2005): Dietary yeast RNA supplementation reduced mortality by Aeromonas hydrophila in rohu (Labeo rohita L.) juveniles. Fish and Shelfish Immunology, 19: 281-291.

Dhama, K. and Singh, S.D. (2010): Probiotics improving poultry health and production: an overview. Poultry Punch, 26(3): 41.

Diab, A.S.; El-Nagar, G.O. and Abd-El-hady, Y.M. (2004): Evaluation of Nigella Sativa L. (Black Seeds, Barka), Allium Sativum (Garlic) \& Blogen as feed additives in Fish cluture $O$. niloticus. SCMJ, 2: 557-562.

Direkbusarakom, S.; Yoshimizu, M.; Ezura, Y.; Ruangpan, L. and Danayadol, Y. (1998): Vibrio spp., the dominant flora in shrimp hatchery against some fish pathogenic viruses. J Mar Biotechnol, 6: 266-267.

Doumas, B.T.; Watson, W.A. and Biggs, H.G. (1971): Albumin standard and the measurement of serum albumin with bromocresol green Clin Chim Acta, 31: 87-96.

Eissa, A.E.; Moustafa, M.; El-Husseiny, I.N.; Saeid, S.; Saleh, $O$. and Borhan, T. (2009): Identification of some skeletal deformities in some freshwater teleost raised Egyptian aquaculture. Chemosphere, 77: 419-425.

Elkamel, A.A. and Thune, R.L. (2003): Invasion and replication of Photobacterium damselae subsp. piscicida in fish cell lines. J Aqua. Ani. Hea, 15: $167-174$.

Fagbenro, O.A. (1998): short communication apparent digestibility of various legume seed meals in Nile tilapia diets. Aquaculture International, 6(1): 83-87.

FAO (2005): Aquaculture production, 2003: Year book of Fishery Statistics - Vol. 96/2. Food and Agriculture organization of the United Nations, Rome, Italy.

Fuller, R.A. (1989): review: probiotics in man and animals. J Appl Bacteriol, 66: 365-378.

Ghatak, S.; Agarwal, R.K. and Bhilegaonkar, K.N. (2007): Species identification of clinically important Aeromonas spp. by restriction fragment length polymorphism of 16S rDNA. Letters in Applied Microbiology, 44: 550-554.

Hatab, M.H.; Elsayed, M.A. and Ibrahim, N.S. (2016): Effect of some biological supplementation on productive performance, physiological and immunological response of layer chicks. Journal of Radiation Research and Applied Sciences, 9(2): 185-192.

Henry, R.F.; Cannon, D.C. and Winkelman, J.W. (1974): Clinical Chemistry Principles and 
Technics. 2nd Ed, Harper and Row, Harper and Row, Hargersein, M.D.

Hillmann, G. and Beyer, G. (1967): Rapid determination of serum potassium by turbidity measurement with kalignost after protein precipitation. Z Klin Chem KlinBiochem, 5(2): 93-94.

Huang, J.; La Ragione, R.; Nu-nez, A. and Cutting, S. (2008): Immunostimulatory activity of Bacillus spores. FEMS Immunol Med Microbiol., 53 (2): 195-203.

Iqramul Haque, Md.; Ahmad, N. and Miah, M.A. (2017): Comparative analysis of body weight and serum biochemistry in broilers supplemented with some selected probiotics and antibiotic growth promoters. Journal of Advanced Veterinary and Animal Research, 4 (3): 288-294.

Irianto, A. and Austin, B. (2002): Probiotics in aquaculture. J Fish Dis, 25: 633-642.

Kamgar, M.; Reza Pourgholam, R.; Ghiasi, M. and Ghane, M. (2013): Studies on Bacillus subtilis, as Potential Probiotics, on the Biochemical Parameters of Rainbow trout, Oncorhynchus mykiss (Walbaum) to Challenge Infections. Advanced Studies in Biology, 5(1): 37-50.

Kaplan, A. and Szalbo, J. (1983): Clinical chemistry :Interpretation and techniques, $2^{\text {nd }}$ ed. A Kaplan, J Szabo, editors, p 157.

Karunasagar, I.; Ali, A.; Otta, S.K. and Karunasagar, I. (1997): Immunization with bacterial antigen: Infection with motile Aeromonas. In: Gudding R.A., Lillehaug, Midthyng J, editors. Fish Vaccinology, Dev. Biol. Stand, 90: 1-7.

Kunttu, H.M.; Valtonen, E.T.; Suomalainen, L.R.; Vielma, J. and Jokinen, I.E. (2009): The efficacy of two immunostimulants against Flavobacterium columnare infection in juvenile rainbow trout (Oncorhynchus mykiss). Fish \& Shellfish Immunology 26: 850-857.

Marzouk, M.S.; Moustafa, M.M. and Mohamed, N.M. (2008): Evaluation of immunomodulatory effects of some probiotics on cultured Oreochromis niloticus. 8th International Symposium on Tilapia in Aquaculture, 10431058.

Miranda Alatriste, P.V.; Urbina Arronte, R.; Gómez Espinosa, C.O. and Espinosa Cuevas Mde L. (2014): Effect of probiotics on human blood urea levels in patients with chronic renal failure. Nutr Hosp, 29(3): 582-590.

Mohamed, K.A.; Abdel Fattah, B. and Eid, A.M.S. (2007): Evaluation of using some feed additives on growth performance and feed utilization of monosex Nile tilapia (Oreochromis niloticus) fingerlings. Agricultural Research Journal, Suez Canal University, 7(3): 49-54.

Nayak, S.K. (2010): Probiotics and immunity: A fish perspective. Fish Shellfish Immunol, 29: 2-14.
Nayak, S.K.; Swain, P. and Mukherjee, S.C. (2007): Effect of dietary supplementation of probiotic and vitamin $\mathrm{C}$ on the immune response of Indian major carp, Labeo rohita (Ham.). Fish Shellfish Immunol, 23: 892-896.

Nikoskelainen, S.; Ouwehand, A.C.; Bylund, G.; Salminen, S. and Lilius, E.M. (2003): Immune enhancement in rainbow trout (Oncorhynchus mykiss) by potential probiotic bacteria (Lactobacillus rhamnosus). Fish and Fish Immun, 15: 443-452.

Panigrahi, A.; Kiron, $V_{. ;}$Puangkaewa, J.; Kobayashib, T.; Satoh, S. and Sugita, $H$. (2005): The viability of probiotic bacteria as a factor influencing the immune response in rainbow trout Oncorhynchus mykiss. Aquaculture, 243: 241-254.

Peddie, S.; Zou, J. and Secombes, C.J. (2002): Immunostimulation in the rainbow trout (Oncorhynchus mykiss) following intraperitoneal administration of Ergosan. Vet Immunol Immunopathol, 86: 101-113.

Roberts, R.J. (2001): The immunology of teleost. In: Roberts R J, Ed. Fish pathology. London: W.B. Saunders 1: 133-150.

Safinaz, R.A.A. (2006): Clinicopathological studies on the effect of growth promoters in Nile tilapia. M. V. Sc., Thesis, Faculty of Veterinary Medicine, Cairo University.

Sahoo, P.K. and Mukherjee, S.C. (2001): Immuonocompressive effect of aflatoxin B1 in Indian major carp (Labeo rohita). Comp immunol Micro Inf Dis, 24: 143-149.

Salim, H.A.; Abd-Allah, O.A. and Fararh, K.M. (2011): Effect of feeding probiotic on hematological, biochemical properties and immune response in broiler. Benha Veterinary Medical Journal, 22: 35-43.

Saurabh, S. and Sahoo, P.K. (2008): Lysozyme: an important defence molecule of fish innate immune system. Aquaculture Research, 39: 223-239.

Sharp, G.J. and Secombes, C.J. (1993): The role of reactive oxygen species in the killing of the bacterial pathogen Aeromonas salmonicida by rainbow trout macrophages. Fish Shellfish Immunol, 3: 119-129.

Siwicki, A.K.; Anderson, D.P. and Rumsey, G.L. (1994): Dietary intake of immunostimulants by rainbow trout affects non-specific immunity and protection against furunculosis. Vet. Immunol. And Immunopathol, 41: 125139.

Song, Z.F.; Wu, T.X.; Cai, L.S.; Zhang, L.J. and Zheng, X.D. (2006): Effects of dietary supplementation with Clostridium butyricum on the growth performance and humoral immune response in Miichthys miiuy. J. Zhejiang Univ. Science B, 7(7): 596-602.

Stoskopf, M.K. (1993): Fish Medicin. 1st ed. Philadelphia: W.B. Saunders. 
Sun, Y.Z.; Yang, H.L.; Ma, R.L. and Lin, W.Y. (2010): Probiotic applications of two dominant gut Bacillus strains with antagonistic activity improved the growth performance and immune responses of grouper Epinephelus coioides. Fish Shellfish Immunol, 29: 803809.

Tietz, N.W. (1986): Textbook of clinical chemistry. WB saunders, philadelphia, pp 1271- 1281.

Verschuere, L.; Rombaut, G.; Sorgeloos, P.; and Verstraete1, W. (2000): Probiotic bacteria as biological control agents in aquaculture. Microbiol Mol Biol , 64: 655-671.

Whyte, S.K. (2007): The innate immune response of finfish--a review of current knowledge. Fish Shellfish Immunol, 23: 1127-1151.

Yáñez, M.A.; Catalán, V.; Apráiz, D.; Figueras, M.J. and Martínez-Murcia, A.J. (2003): Phylogenetic analysis of members of the genus
Aeromonas based on gyrB gene sequences. Int. J. Syst. Evol. Microbiol, 53: 875-883.

Yano, T.; Mangindaan, R.E.P; and Matsuyama, H. (1989): Enhancement of the resistance of carp Cyprinus carpio to experimental Edwardsiella tarda infection, by some -1,3 -glucans. Nippon Suisan Gakkaishi, 55: 1815-1819.

Yeh, S.P.; Chang, C.A.; Chang, C.Y.; Liu, C.H. and Cheng, W. (2008): Dietary sodium alginate administration affects the fingerling growth and resistance to Streptococcus sp. and iridovirus, and juvenile non-specific immune responses of the orangespotted grouper, Epinephelus coioides. Fish Shellfish Immunol, 25: 19-27.

Young, D.S.; Pestaner, L.C. and Gibberman, V. (1975): Effects of drugs on clinical laboratory tests. Clin Chem., 21(5): 1D-432D.

\section{التأثيرات المناعية المحتملة لبروبيتيك برو-باك الغذائي في أسماك القرموط الأفريقي

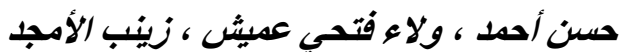

E-mail: hassan-younes@vet.svu.edu.eg Assiut University web-site: www.aun.edu.eg

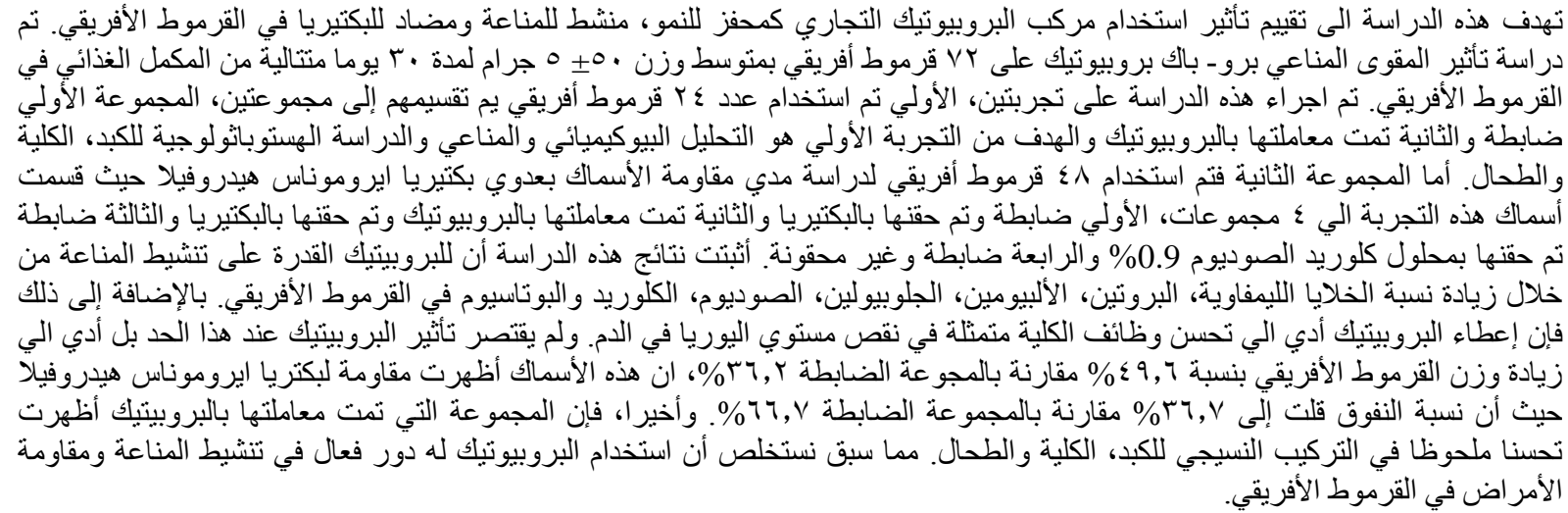

